\title{
Discussing quality: critical vocabularies and popular television drama ${ }^{1}$
}

\author{
Christine Geraghty ${ }^{2}$ \\ University of Glasgow
}

\begin{abstract}
British soap operas have a history which is rooted in realism, a strong sense of community and the serious treatment of social issues. This essay argues that in the late 9os/early 20oos British soaps have adopted a more melodramatic aesthetic with an emphasis on the isolated individual, extreme situations, symbolic landscapes and moral polarity. Following Zygmunt Bauman, it suggests that such changes reflect the feeling that the idea of society is under siege.
\end{abstract}

Key words: soap opera, melodrama, community, British television, Zygmunt Bauman; EastEnders.

Resumo: As soap operas britânicas têm uma história enraizada no realismo, um forte senso de comunidade e um tratamento sério de questões sociais. Este ensaio sugere que, no final dos anos 90 e início dos anos 200o, as soap operas britânicas adotaram uma estética mais melodramática com uma ênfase no indivíduo isolado, nas situações extremas, nas paisagens simbólicas e numa polaridade moral. Seguindo Zygmunt Bauman, sugiro que estas mudanças refletem o sentimento de que a idéia de sociedade está sob ataque.

Palavras-chave: soap opera, melodrama, comunidade, televisão britânica, Zygmunt Bauman, EastEnders.

\footnotetext{
${ }^{1}$ This article is based on an essay 'Discussing quality: critical vocabularies and popular television drama' published in Media and Cultural Theory, J Curran and D. Morley (eds), Oxford: Routledge, 2006, pp 221-232.

2 Christine Geraghty is Chair of Film and Television Studies in the Department of Theatre, Film and Television Studies at University of Glasgow. She is also an editor of the Journal of British Cinema and Television and a member of the Editorial Advisory Boards of Screen, International Journal of Media and Cultural Politics, Art, Design and Communication in Higher Education and Critical Studies in Television. Christine is chairperson of the Media, Communications and Cultural Studies Association. She is the author of a number of books and articles on film and television, most recently British Cinema in the Fifties: Gender, Genre and the 'New Look' and is working on a study of My Beautiful Laundrette.
} 
The terms 'quality' and 'soaps' are seldom linked in discussions of television. In a British context, whether set against single plays of the sixties, classic serials of the eighties or US HBO series in the nineties, soaps generally represent the worst tendencies of formulaic, repetitive and aesthetically predictable television. For many quality television fiction now comes in the shape of US series and sit coms (see Jancovich and Lyons) and Lez Cooke in a recent history of British television drama found no soaps to add to his list of contemporary British programmes which could challenge the best of US television. In media and cultural studies, soaps tend to be studied in terms of their audiences, their social significance and their narrative organisation. Arguments about quality involve attention to textual detail which is hard to maintain as yet another episode sweeps by.

This essay seeks to make a number of arguments about the aesthetic mode of a particular soap, BBC1's EastEnders. I will argue that EastEnders, a continuous serial which revolves around a number of families living in Albert Square, has in recent years developed a distinctive aesthetic based on a bold use of melodrama for its most effective and disturbing storylines; that this can be linked to a decline in the possibilities of community which have traditionally been the distinctive feature of British soaps; and that television criticism lacks the vocabulary to judge a soap like EastEnders as television drama. In the process of making the argument, I need to stop the flow of EastEnder's narrative and subject isolated episodes to the kind of textual analysis which might be given to other forms of television drama. This essay therefore focuses on a particular week (1st-5th October 2001) when a special storyline, spread across four episodes, revealed the secrets of the Slaters. The Slater family, a relatively recent addition to the soap, consisted of a battle-axe of a grandmother, a widowed father, Charlie, and five daughters; an uncle, Harry, had followed them to the Square and become engaged to Peggy Mitchell, the soap's prime matriarch. During the week, it was revealed that Zoe, at 17 the youngest in the family, was in fact the daughter of one of her sisters, Kat. She had been conceived in an abusive relationship between Kat, then aged 13, and her uncle, Harry, though Charlie had not known that his brother was the father. The revelations occurred on the eve of the wedding of another of the sisters, Lynne, and caused a great deal of 
anguish. The week ended with father punching brother, the wedding abandoned, Kat attempting suicide and Zoe running away from her disrupted home3.

In a British critical context, soap operas tend to be valued insofar as they operate in a realist mode. David Hare, for instance, praised EastEnders for creating television drama which recognises 'that the editing and organisation of reality is a genuine skill' (2002). Realism has also been a defense against the criticism that soaps are too violent and salacious; it was characteristic that the producer, John Yorke, defended the abuse storyline on the grounds that 'we try and reflect the world as it is' (quoted in The Observer, 7 October 2001). This links to a public service function of educating audiences about the modern world, a remit which could fit Kat's abuse alongside the stories of rape, domestic violence, drug use and AIDS which have featured since the programme began in 1985. Accuracy and social responsibility are watchwords here as Yorke demonstrated when he defended the story by using the realist concept of changing the world by exposing its flaws:

before we plotted it, we talked to the Samaritans, to child psychiatrists and to the NSPCC. All said the same thing - "This story needs telling. Will you please let people know that this goes on". (Yorke, 2002)

This education process involves showing how characters learn to understand and accept problematic situations in their community. British soap operas often focus on communities which provide moral and social support to characters in difficulties and which celebrate their own solidarity. While the representation of community is sometimes seen as excessively nostalgic, it is still presented as a microcosm of British society and an important resource for characters in trouble. Given all this, claims about EastEnders' status as drama tend to rest on its continuation of the valued traditions of representational realism with stories rooted in social obligations and communal relationships.

But the story of the Slater sisters had a rather different approach, one which foregrounded the aesthetic pleasures of its telling. The four episodes put a social problem into a familiar context - the characters and spaces of Albert Square, the

3 A DVD about the Slaters was issued by the BBC in November 2003 and this episode is one of a number featured on the BBC's EastEnders classic clips website at http://www.bbc.co.uk/eastenders/classicclips/classic_kat_zoe.shtml 
expected narrative events of the stag night and the hen party, the doubts of the groom and the settled, rather unromantic convictions of the bride. But out of this familiar material was made a story which layered past on present, created precarious understandings between characters which were immediately challenged and used its mise-en-scene to present a world transformed. The episodes were formally balanced; the first and last worked with the traditional parallel stories of a soap, while episode two focused on Kat and Zoe and episode three, though less intensely, on Charlie's response to the news that his brother had abused his child. There were rhythms within episodes; episode two was a long two-hander between Kat and Zoe in which they came together and parted, whispered and shouted, fought and were still. The camera work was more elaborate than usual; a moving camera around the table at the women's celebration matched the ebb and flow of the jokes and stories, weaving the women into intimacy while close-ups scrutinised individual reactions. Unusual devices - the voice-overs of the women, in the first episode, as the visuals showed their men, extreme close-ups of eyes at painful moments - drew attention to the miseen-scene while, less overtly, the use of closed doors to separate characters and open doorways to frame them underpinned Kat's tale of how she, as a frightened girl, had overheard the adults deciding what should be done with her and her unborn baby. Stories and photographs, a common way of referring to the past in soaps, were reinforced in the final episode by highly unusual flashbacks of the catastrophic event. Acting was showcased; as Jessie Wallace recreated her character as a child, she lightened her voice and changed her facial expression so that the 13 years old Kat could be seen struggling through. The writing could handle not only Kat's set-pieces but Garry's solemn ruminations on the nature of love, Charlie's fierce responses and Zoe's shift from a proud assertion of self-confidence at the hen night to mute incomprehension in the final episode.

Crucially, the motif of the moon bound this complex mise-en-scene together. The first episode begins with a shot of the moon shining over the square and the strains of 'Blue Moon' can be heard from the pub. In the 'truth or dare' game at the hen night, Dot tells of a stolen kiss and astonishingly finishes the story with a quotation from Dylan Thomas about the 'mile high moon'. The alternating party scenes are bathed in warm light and bright colours but other, more intimate scenes 
are lit by the cold, blue moonlight. Zoe, for instance, listens to the first part of Kat's account from behind the closed door of her bedroom, her face turned up to the moon. The motif of the moon is specifically alluded to, in a key scene in the third episode, when Kat reminds her father of the promise he had made her, when she was six years old, that the Man in the Moon who would keep her safe when she was in bed. As the moon shines in on the grownup Kat, she tells her father how the moon had shone down on her when Harry had entered her room to abuse her, making her realise that, despite her father's promise, she was no longer safe. Later, Kat looks up at the moon as she sits in the square, planning suicide. And the final image of the week was of a full moon, dramatically filling the screen as Zoe left the Square and Kat looked up from her hospital bed.

Is it fanciful to link this to a Victorian narrative painting 'Past and Present' by August Egg, a work of rather different artistic prestige, which hangs in Tate Britain gallery? It is a tryptich, telling the story of a fallen woman. The central larger picture shows the adulterous wife, lying on the floor, having apparently been pushed away by her husband while her small daughters look uncomprehendingly on. The pictures on either side show the situation years later: in one, the rejected wife is destitute, sheltering at night under an arch looking over the Thames; in the other, her grownup daughters are alone and sad in a bare room. In these two pictures, the implacable moon shines down, just as it had on Kat and Zoe, giving a temporal unity to the two scenes but emphasising the desolate isolation of the scattered family. 'Past and Present' is working within a strong tradition of melodrama and it is this term we need to use to understand what is going on in these episodes of EastEnders

Melodrama, a negative word for television critics, tends to be seen as a strong but undesirable element in British television, marked by stock characters, predictable narrative moments and over-wrought acting. But in its handling of the abuse storyline, EastEnders seemed to be drawing on something more dynamic which, in its theme and use of metaphors, was more akin to the definitions of melodrama developed outside television studies. In looking at cinema, Christine Gledhill (1987) drew specifically on Peter Brook's study, The Melodramatic Imagination, for her influential discussion of how the term might be used in film analysis. She identified a number of features of melodrama which included: the 
notion of melodrama as an aesthetic response to the social upheaval in society; the construction of a highly polarised world view in which good and evil are clearly delineated and in which evil threatens to overwhelm good; the personification of good as an innocent woman and sexual seduction or rape as the vehicle of the threat; and the eventual assertion of good when the woman speaks in order to name and identify evil. The enactment of this struggle, Gledhill suggested, 'draws into a public arena desires, fears, values and identities which lie beneath the surface of the publically acknowledged world' (33)4.

Just as the parallels with 'Past and Present' help to position the aesthetic devices of these EastEnders episodes so this broader description of nineteenth century melodrama illuminates the story of the Slaters in which the rape of Kat and the secret of Zoe's birth are finally made public. Kat's strong maternal feelings, Zoe's confusion about her identity, Charlie's unacknowledged disgust at his own daughter's pregnancy struggle up to the surface and have to be faced. The abuser is identified and Kat confronts Harry as evil, insisting on the fact of her innocence while despairing at the way the abuse had distorted her sexual feelings. Yorke later described the story as a morality play which involved 'helping others, exposing evil and giving voice to the voiceless' (2002), a classic description of the melodramatic impulse.

Why then should EastEnders use melodramatic tropes to tell this story despite the undervaluing of this mode on British television? With their strong tradition of dealing progressively with social issues, British soaps claim to provide reassurance and support for women both in the storylines (women work to re-claim their own lives) and the helplines which are advertised at the end of each episode. So we could see the Slater story as a reflection of contemporary issues with perhaps a sensationalist element generated by the story's connections to the "name and shame" approach of the popular press. But that does not seem to explain fully the story's intensity and, in particular, the use of the moon not just as a striking image but as an over-full signifier comparable to that of the Victorian painting. Such imagery seemed

4 It has been more common to discuss US programmes in terms of this broader approach to melodrama. See in particular Feuer and Gripsrud for discussions of US prime time soaps. 
to indicate a more overwhelming sense of loss and of fate being worked out under the implacable moon.

Gledhill, following Brook, linked film melodrama to broader upheavals in society and I would suggest that something similar is happening with British soaps at the beginning of the twenty-first century. One of the key issues in the storyline is lack of trust. Zoe is shattered to learn that the family relationships she had taken for granted were based on lies. Kat's trust in the adults of her family, her father and mother as well as her uncle, had been abused since one result of her uncle's abuse is that her own father believes her to be sexually guilty. Questions of trust, risk and instability have been much debated by contemporary philosophers and sociologists, including Zygmunt Bauman. Drawing on a range of work on globalisation and the risk society, Bauman, in Society under Siege, argues that we increasingly find ourselves in a position in which we can trust in nothing except, rather despairingly, ourselves. Global business practices demand fluid and unstable modes of organisation which nation-states are proving powerless to control or ameliorate. Families, communities and relationships all seem vulnerable, jobs are on short contracts, skills become obsolete. The nation state, he argues, is becoming incapable of providing the economic and social support we call society and individuals are thrown back on 'biographical solutions' $(2002,36)$, individual attempts to deal with uncertainty by seeing life as a series of new starts, of relationships which are never stable and of self-improvement plans which are never achieved. 'What seems to be gone' he suggests 'is the image of society as the "common property" of its members which at least in principle can be conceivably tended to, run and managed in common' (49). And if private life has become something individuals try to manage rather than something that the state organises, then outside ourselves we have 'a horrifying sense of a world that is neither managed nor, as far as one can see, manageable' (18).

Bauman himself uses television for some of his examples and his work can be well applied to British soap opera. If we accept that the structures and stabilities which sustained the idea of society are under siege, we can see that this might pose specific problems for television programmes which have their basis in the realist representation of a socially cohesive world. For a time, British soap operas indeed 
seemed to be working against the notion that society was irrelevant, a point the BBC's Head of Drama, Mal Young, specifically made when defending them at a television conference:

Mrs Thatcher used the 8os to dismantle the community, encouraging us to become more self-obsessed, while all along we clung to the hope and optimistic feeling that still existed in our soaps' (quoted in The Guardian, 17 September 1999)

The emphasis was on communal action at times of crisis, on people's day-today contacts with their neighbours and on clear roles for a variety of individuals who were connected in a common space. The characters and stories which came out of this nexus provided a vivid illustration of how society could, to repeat Bauman's phrase, be 'tended to, run and managed in common'. That this process was sometimes difficult and fractious, especially in EastEnders, is less important for this argument, than the example it offered of how society, in a local and national context, could be conceptualised.

It seems to me, however, that the Slater story is an example of how the increasing use of melodrama on British television can be seen not as a set of devices nor indeed a response to the production conditions necessary to produce the required number of episodes but as an expression of an aesthetic world view. The turn to melodrama can be understood as a way of trying to fill the vacuum created by the instabilities and lack of trust which Bauman describes and the consequent inadequacies of realism as an explanatory mode. And so gradually in EastEnders we can see a different aesthetic taking shape marked by the following shift:

$\underline{\text { Traditional realist modes }}$

relative moral values

consistent, complex characters

www.compos.com.br/e-compos
Melodramatic modes

extremes of good and evil

characters reworked to personify

good and evil in particular stories 
characters in relationships,

relationships to be worked through

strong women characters

stories as ongoing

everyday stories with liberal

lessons

deferral of moral judgments

territorial, internal geography,

space defined by community

time in parallel with viewer

talk and discussion

no music

continuous stories

significant objects embedded

urban space, manmade setting

melodramatic devices restrained by realism

www.compos.com.br/e-compos isolated characters, relationships

to be escaped from

women as victims

stories as special events

extreme stories of death, violence

clear moral judgments

symbolic spaces (gravesides

cliff edges) outside soap's territory

time organised dramatically

visual rendering of emotional state

music (but still diegetically sourced)

endings

symbolic objects highlighted

weather, countryside, nature as symbolic devices

melodramatic devices feed into sensationalism 
stoicism, endurance, getting by

community as a resource crying, fighting, going for broke

individuals outside society

The differences between the two modes indicate a shift which has several dimensions - a shift from the emphasis on individuals in a community to those who feel isolated and unsupported; a change in the deployment of time and space to emphasise that moral isolation; a change in aesthetics with a greater emphasis on symbols, settings, camera work and lighting which help to express inner emotion. And although, traditional morality normally wins out and the bad characters suffer or disappear, the effect of this shift to the melodramatic mode is to present a world which is darker and more precarious than before, to represent indeed a society under siege.

Kat and Zoe's story demonstrates a number of features associated with the melodramatic mode. This was a special story, trailed extensively as a special event. The usual organisation of time on a day-by-day basis was abandoned so that while the episodes ran through the week the events told occurred in a single night. Objects such as the moon, Zoe's teddy bear and a whiskey bottle are given close-ups which emphasise their symbolic meaning rather than their function as realist props. The task of the story is to delineate clearly the evil action of abuse and to demand clarity of judgment; Charlie's muddled attempt to see more than one point of view is singled out as inappropriate. For this to happen, Kat has to be re-invented as innocent, hence the emphasis in the mise-en-scene on recreating the childhood scene of the moon shining into her bedroom; it is significant also that during these scenes Lynne's white wedding dress hung on the bedroom door, a reminder of Kat's loss and a visual reinforcement of the white light of the moon. Although other family members tried to help, Kat and Zoe were presented as isolated victims not only of specific events but of fate itself; indeed, once Harry had been driven out, Peggy was also shown sitting alone and abandoned in the moonlight. All three women were, at this point, beyond the help which might be offered by the community's social structures. While the action was not particularly violent, it was characterised by the direct expression of 
extreme emotion, particularly in the second episode, a two-hander between Kat and Zoe. And finally the five episodes worked as a whole, with the story raised and resolved during this period, the resolution being given narrative form with the expulsion of Harry and Kat's recovery from her suicide bid and aesthetic closure achieved by the final image of the moon which referred back to the first shot.

EastEnders has not entirely abandoned the traditional forms of its origins. Indeed, it is possible to identify strong elements of its more usual stoical realism in these episodes, for instance, in the communal way in which the drunken Garry and his friends celebrate his stag night. Other dramatic stories since 2000, including, I would argue, most of a storyline dealing with the domestic violence suffered by another Slater sister, Little Mo, continued to be handled in the more progressive realist manner of the community-orientated British soap. It is also true that EastEnders has since its inception called on melodramatic tropes for some of its stories and characters, in particular in its representation of the dastardly Nick Cotton who had the evil panache of a Victorian villain.

However, I would argue that, in the early 2000s, the programme has adopted melodramatic tropes more consistently and boldly for its big storylines and that the aesthetic is used not only for the clear delineation of morality but to express a darker vision of the world than was previously the case. Other examples of such storylines, most of which were screened in ways which diverged from the normal schedule, would be the argument between Phil and Lisa about the disputed custody of their child which took place on the edge of a cliff in a remote part of Portugal; the death of Jamie in which the motif of the moon, this time as a symbol of constancy, reappeared; the kidnapping and fire which brought to an end Trevor's reign of terror over his wife Little Mo in contrast to the legal system which had failed her; and perhaps the most extraordinary story of all in this context, Dot Cotton's crisis of faith in which she was shown weeping in the empty church, abandoned by God 5 .

\footnotetext{
5 Bauman himself, comparing Little Mo to Antigone, commented that 'one can hardly hear the residents of Albert Square mentioning God (the few who do, quickly disappear from the soap saga, as blatantly out of place)' (2003, p27). Dot's existential drama proved the dangers of being too prescriptive about what might happen in soap opera. This shift to melodrama is also taking place in another British soap, Coronation Street, though I would argue that it was much less well handled in the 2002/3 story of Richard, the husband as serial killer.
} 
It is perhaps important to note that the programme presses its melodramatic stories not as post-modern pastiches to be watched ironically but as emotionally saturated expressions of loss. John Ellis suggested that television 'provides a relatively safe area in which uncertainty can be entertained, and be entertaining' (82). Watching EastEnders is not in the great scheme of things 'unsafe' and yet it seems to me that the programme has been giving full rein to the perils of uncertainty in a way which is made the more poignant because of the previous notion of the positive resources of community and social progress. Melodrama is supposed to be an ameliorative and consoling form in which order is restored but, in this version of it, the capacity of melodrama to represent the fears beneath the surface challenges its capacity to assuage them.

\section{Bibliography}

Bauman Z (2002) Society under Siege, Cambridge: Polity.

-- (2002) Liquid Love, Cambridge: Polity.

L Cooke (2003) British Television Drama, London: BFI.

$\mathrm{J}$ Ellis (2000) Seeing Things Television in the Age of Uncertainty, London: I.B.Taurus.

J Feuer, (1995) Seeing through the Eighties: Television and Reaganism, Durham: Duke University Press.

C Gledhill (1987) 'The melodramatic field: an investigation', Home is Where the Heart is, London: BFI.

J Gripsrud (1995) The Dynasty Years Hollywood, Television and Critical Media Studies, London: Routledge.

D Hare (2002) 'Why fabulate?', The Guardian, Saturday Review, $2^{\text {nd }}$ February. M Jancovich and J Lyons (eds) (2003) Quality British Television, London: BFI.

J Yorke (2002) 'Our modern morality plays', The Guardian, $4^{\text {th }}$ September. 